\title{
PROPENSITY TO RISK OF STUDENTS IN RELATIONSHIP WITH THEIR PSYCHOLOGICAL RESOURCE
}

\author{
Mariia Kazanzhy \\ South Ukrainian National Pedagogical University named after K.D. Ushynsky, \\ 26, Staroportofrankovskaya str., Odesa, Ukraine, 65023 \\ e-mail: kazanzhy.mariya@gmail.com \\ Oksana Vdovichenko \\ South Ukrainian National Pedagogical University named after K.D. Ushynsky, \\ 26, Staroportofrankovskaya str., Odesa, Ukraine, 65023 \\ e-mail:werta4877@gmail.com
}

The report contains the results of a theoretical and empirical researching of the aerobatic nature of the psychological resourcefulness of students with varying degrees of propensity to risk. The lack of a single view in psychological science on the problem of risk, which is multifaceted and mainly studied in terms of three stages - personal, cognitive and situational. The propensity to risk is considered by us as an individual property, which distinguishes the behavior of the individual in similar situations. A limited number of works have been identified to identify the relationship between propensity to risk and psychological resourcefulness of the individual in the student age.

The following psychodiagnostic tools were used in the empirical study: "Questionnaire of psychological resourcefulness of personality" (Shtepa, 2018) and "Questionnaire risk propensity in different spheres of activity" (Vdovichenko, 2007). The study sample consisted of students (100 people).

According to the results of correlation analysis, there are only negative significant correlations between most components of psychological resources and risk propensity indicators in different areas of activity, the most extensive and strong negative correlates were found between risk parameters and the ability to accommodate and update their own psychological resources and their overall level. According to the information obtained, we can note the dependence of the reduction of psychological resources, their depletion in all areas of risk, which can be interpreted due to lack of experience, practical skills to overcome such situations. It is important to note that students are not at all at risk and have a high level of all components of psychological resources.

In general, students at risk have reduced psychological resources. Low level of such resources as faith in the good, work on yourself, kindness to people, helping others, love, etc., that is resource components based on the value-semantic basis of the individual. Therefore, in practical work it is necessary to focus on this side, if there is a task to reduce the risky behavior of students and enrich their psychological resources. The obtained data are the basis for continuing the study with a more extensive sample both in terms of age and professional affiliation.

Key words: propensity to risk, spheres of manifestation of risk, psychological resourcefulness, resource components. 


\title{
УДК 159.95
}

DOI https://doi.org/10.30970/PS.2021.8.9

\section{ВПЛИВ БІЛІНГВІЗМУ НА КОГНІТИВНИЙ РОЗВИТОК ОСОБИСТОСТІ}

\author{
Яна Кайманова \\ Донещький інститут Міжрегіональної Академії управління персоналом, \\ вул. Уральська, 12, м. Краматорськ, Донеиька область, Україна, 84333 \\ e-mail: kramatorsk.institute.maup@gmail.com \\ Надія Рябоконь \\ Донецький інститут Міжрегіональної Академії управління персоналом, \\ вул. Уральська, 12, м. Краматорськ, Донеиька область, Україна, 84333 \\ e-mail: kramatorsk.institute.maup@gmail.com
}

У статті розглядаються останні дослідження, присвячені впливу білінгвізму на когнітивний розвиток особистості. Експериментальні наукові дослідження, зроблені останнім часом, не тільки зруйнували міф про шкоду двомовного розвитку особистості, а й показали, що воно дає набагато більше, ніж просто знання двох мов. За допомогою мов ми пізнаємо світ у всьому його різноманітті, кожна вивчена мова відкриває нам нові засоби сприйняття, мислення та пізнання. Засвоюючи нову для себе мову, людина одночасно пізнає і новий світ. Білінгвізм розширює межі нашого мислення та пізнання. На основі порівняльного аналізу показані переваги дітей і дорослих, що 3 народження перебувають у білінгвальному середовищі. Такі переваги полягають у наявності металінгвістичних здібностей, що дозволяють, зокрема, збільшити швидкість навчання; в кращому, ніж в однолітків-монолінгвів, розвитку виконавчих функцій (виконавчого контролю, уваги, вміння планувати дії, концентрації), важливих не тільки для виконання вербальних завдань, а й для управління будь-якою діяльністю. Показано також вплив білінгвізму на когнітивну децентрацію, здатність до вивчення інших мов, на формування високого ступеня соціальної чуйності, що належить як до вербальної, так і до невербальної комунікації (інтерпретації міміки, жестів, інтонації) і виражається в найадекватнішій реакції на мову й комунікативну поведінку оточення. Білінгвізм розширює межі мислення та пізнання. Освоєння нової мови приводить до подальшого розвитку й збагачення єдиної мовної особистості індивіда в лінгвістичному, когнітивному, комунікативному аспектах.

Білінгвізм стимулює творчість, сприяє розвитку дивергентного мислення, що дозволяє розглядати безліч можливих рішень однієї й тієї ж проблеми й виробляти, таким чином, креативні ідеї. Знання двох мов розширює ментальні кордони дитини, яка з культурного й лінгвістичного боку буде краще підготовлена до вступу в життя, ніж ії ровесники.

Ключові слова: білінгвізм, монолінгв, когнітивний розвиток, виконавчі функції, децентрація.

Вивчення іноземних мов, безсумнівно, є корисною для мозку діяльністю, вона розширює горизонти й межі світогляду людини й зростає в двомовному середовищі. Останні дослідження, присвячені білінгвізму, не тільки зруйнували уявлення про його шкоду, але й показали, що двомовний розвиток сприяє більш різнобічному становленню особистості.

Досвід використання двох мов із дитинства має цілий ряд як лінгвістичних, так і екстралінгвістичних позитивних ефектів. Діти легше засвоюють мови, для них властиво «грати» зі словами, вони не бояться помилятися; крім цього, в їх пам'яті тільки ще формується система звуків і слів, яка із часом консолідується, ускладнюючи освоєння другої мови.

Феномен білінгвізму розвиває метакогнітивні й металінгвістичні здібності особистості. Е. Біалісток, працюючи з двомовними дітьми, компетентними в обох мовах, вста-

(C) Кайманова Яна, Рябоконь Надія, 2021 
новила, що білінгви мають підвищений контроль над лінгвістичними процесами, який виражається в здатності аналізувати когнітивні й комунікативні компоненти [7]. Знання другої мови сприяє усвідомленню довільних зв'язків, що існують між словами й значеннями, що сприяє легшому й швидшому вибору й кодуванню інформації.

Л.С. Виготський зазначав: «Відділення значення від звуку, слова від речі, думки від слова $\epsilon$ необхідними ступенями в історії розвитку понять» [2, с. 340]. Завдяки металінгвістичним здібностям білінгви починають читати раніше монолінгвів [10]: раннє опанування читання - наслідок легшого розпізнавання двомовними дітьми системи відповідності «графема - фонема».

Крім того, інтуїтивне розуміння структури мови допомагає білінгвам у подальшому вивченні інших мов. Білінгви легше монолінгвів переходять від одного завдання до іншого там, де потрібна вибіркова увага й здатність ігнорувати інтерферувальні чинники. Це перевага зберігається і в дорослому віці. Головний фактор, що зв'язує білінгвізм із виконавчим контролем, зумовлений тим, що в білінгвів постійно активовані обидві мови. У зв'язку із цим розвивається механізм гальмування (пригнічення), який дозволяє диференціювати ці мови, обмежуючи інтерференцію невикористаної мови у використовуваній.

I.C. Морозова у своїй праці привела приклад дослідження, що було проведено Ж. Мейлером та А.М. Ковачем у Вищій міжнародній школі передових досліджень (Sissa) у м. Трієсті. Воно показало, що виховання у двомовній сім'ї дає дитині переваги в розвитку іiї когнітивної сфери. Учені спостерігали за шістьма одномовними й шістьма двомовними дітьми у віці 12 місяців, яким пропонувалися завдання, що вимагають контролю виконавчих функцій. У ході експерименту дітям були представлені різні вербальні стимули: трискладові слова, що мають відмінні структури (АВА як «лову» або ААВ як «лолова»). Відразу ж після прослуховування звукового стимулу на екрані з'являлася іграшка: зліва, якщо структура була АAB, i справа в разі ABA. Кожна дитина повинна був правильно вгадати сторону, де з'явиться іграшка після звукової стимуляції. Для успішного розв'язання завдання дітям треба було зрозуміти структурну послідовність вербальних стимулів, асоціювати 3 конкретною лінгвістичною структурою одну зі сторін екрану й перевести туди погляд. Двомовні діти, відразу ж зрозумівши відмінність, реагували правильно й швидко, в той час, як їх одномовні однолітки насилу вибирали потрібний варіант і змогли правильно виконати завдання тільки з однією вербальною структурою (ААВ). Таким чином, дослідники дійшли висновку, що білінгвальна дитина засвоює одночасно дві лінгвістичні структури з більшою легкістю та може швидко зорієнтуватися під час зміни ситуації [5].

Пасивне тренування мозку протягом перших місяців життя дозволяє двомовним дітям докладати менше зусиль під час обмірковування та накопичення інформації, що впливає на швидкість навчання. Зазначені вище дослідження вчених спростовують сумніви $з$ приводу можливості змішування мов і пізнішої появи мови в білінгвів. «Навіть якщо двомовна дитина повинна вивчити вдвічі більше слів на відміну від свого одномовного однолітка, вона не буде демонструвати ніякого відставання в розвитку лінгвістичних здібностей. Виголосить свої перші слова так само, як і діти-монолінгви: перше слово приблизно близько року й перші 50 слів близько вісімнадцяти місяців» [5, с. 116].

Л.А. Петіт та її колеги з Дартмунського коледжу, проводячи порівняльний експеримент з одномовними й двомовними дітьми, які вміють читати й писати обома мовами, оцінювали когнітивні здібності дітей за допомогою методу "Simon Task". Результати білінгвів виявилися помітно вище, ніж монолінгвів. «Ми думали, що перші не повинні мати перевагу, оскільки їхній мовний розвиток міг бути уповільнений через плутанину, пов'язаною із засвоєнням двох мов, - коментує Петіт, - проте дослідження це не підтвердило. Навпаки, велика здатність до обчислення, необхідна для перероблення двох різних лінгвістичних систем, збільшує когнітивні здібності дітей» [10, с. 191]. 
Нейронна щільність не знижується до семи років, під час цього періоду максимальної пластичності мозку вищі когнітивні процеси особливо схильні до впливу досвіду й навчання. В юності зростання їх активності припиняється та приблизно до 20 років піддається ремодуляції (перебудові) із запрограмованим знищенням невикористаних зв'язків (Gopnik, 1999 рік). Особистий досвід визначає, які зв'язки будуть посилені, а які ліквідовані: ті з них, які використовувалися більше, збережуться.

Дослідження А. Мічеллі (Інститут когнітивних нейронаук Лондонського університету) виявило, що вивчення іноземної мови збільшує кількість сірої речовини, що міститься в кутовій (ангулярній) звивині лівої тім'яної частки головного мозку (одна із зон мозку, що відповідає за мову). Результати підтвердили, що вчити мову з раннього дитинства простіше: мозок пластичніший і краще піддається змінам. «Тільки в останні дватри роки дослідження в області нейронаук показали, що мозкова структура змінюється залежно від типу ії роботи» [9, с. 431].

Відповідно до результатів дослідження, опублікованих в журналі PNAS Національної академії наук США (М. Cheе, 2004 рік), у вивченні іноземної мови бере участь ліва частина островкової частки півкуль головного мозку (інсула), де розташовується фонологічна робоча (або короткочасна) пам'ять. Мозок збалансованих і незбалансованих (ті, що знають краще одну мову) білінгвів під час лінгвістичного експерименту на прослуховування та запам'ятовування слів працював неоднаково. У перших під час використання методу функціонального магнітного резонансу (далі - ФМР) була помічена активність у зоні фонологічної робочої пам'яті, у других ця зона була менш активна й заміщена роботою інших ділянок. Дані дослідження підтверджують припущення, що короткочасна пам'ять у білінгвів ефективніша.

Сандра Бен-Зеєв виділила чотири основних механізми, що розв'язують проблему на структурному рівні мови в білінгвальному контексті:

1) підвищена здатність до лінгвістичного аналізу, що є стимулом в індивідуальному обмірковуванні й походить від позитивних ефектів мовної інтерференції;

2) чутливість до дій у відповідь сигналам від поверхневої лінгвістичної структури або від вербального ситуативного контексту. Для переходу з однієї мови на іншу білінгву необхідно змінити поведінку, тобто, звертаючи увагу на дрібні деталі кожної ситуації, відреагувати відповідним чином;

3) узагальнення структурних відмінностей між мовами. Двомовна дитина усвідомлює свої лінгвістичні коди як внутрішньо пов'язані системи раніше своїх одномовних ровесників;

4) нейтралізація внутрішньомовних структур. Для розв'язання лінгвістичних складнощів, які з'являються за умови володіння двома структурно різними кодами, білінгв нейтралізує структури однієї з двох мов у точці конфлікту.

С. Бен-Зеєва вважає, що двомовна дитина має більшу соціальну чуйність. Це сприяє тому, що білінгв легше може входити в роль інших, відчувати їхні комунікативні складності та, як наслідок, відповідати на них адекватніше [6, с. 57].

Б. Бенеллі вивчала вплив ефектів білінгвізму на уявлення про ментальні стани. Результати показали, що двомовний досвід допомагає особистості зрозуміти існування різних ментальних станів двох співрозмовників, контролюючи їх поведінку. Вчена пов'язує це з підвищеними здібностями до аналізу ситуацій і з раннім відкриттям існування різних символіко-лінгвістичних уявлень для однієї й тієї ж реальності.

Л.В. Засєкіна вказує на активне застосування білінгвами вербального посередництва й вживання мови як інструменту експресивного й когнітивного регулювання. «Модель психічного» співвідноситься з виконавчими функціями (планування, розв'язання завдань 
і проблем, придушення автоматичних, вироблених реакцій на стимул), тому висока продуктивність білінгвів викликана їх умінням частіше переглядати власні помилкові переконання та погляди [4].

Білінгви краще розпізнають обман, фальш, а також наміри, замасковані іронією. Треба підкреслити, що розуміння іронії зачіпає не тільки рекурсивне мислення першого порядку, а й вищого порядку: «я думаю, що ти думаєш, що я думаю».

Білінгвізм стимулює творчість, що розуміється як здатність активувати й одночасно розробляти складні концепти, які належать різним категоріям; сприяє розвитку дивергентного мислення - процесу, що дозволяє розглядати безліч можливих рішень однієї й тієї ж проблеми й виробляти креативні ідеї.

Відмінності, з якими дитина часто стикається у своєму культурному й соціальному середовищі, примушують ії до уявних операцій, які можуть позитивно впливати на автоматизацію поведінки. Автоматизація сприяє економії когнітивних ресурсів і звільняє їх для розв'язання незнайомих завдань, таких як, наприклад, децентрація. Збалансовані білінгви й поліглоти повинні мати в розпорядженні більше процедурних ресурсів. Декларативне знання аналітичне, містить минулі події та інші фактичні знання, воно легко доступне для суб' єкта й лежить в основі логічного мислення. Процедурне знання, навпаки, неможливо проаналізувати, воно містить неусвідомлювані людиною здатності. Ця когнітивна модальність сприяє автоматизації та дозволяє переробляти велику кількість інформації в порівнянні з «контрольованим» процесом, що вимагає підвищеної уваги з боку людини. Ранні білінгви використовують механізми процедурної пам'яті, пізні - користуються в основному механізмами декларативної пам'яті.

Останні дослідження показують, що деякі з переваг дітей-білінгвів зберігаються в літньому віці, захищаючи їх від згасання когнітивних функцій і затримуючи симптоми старіння. Відомо, що набуті знання та звичні операції (кристалізований інтелект) залишаються незмінними, навіть коли людина старіє, в той час, як здатності, що залежать від утримання уваги на розв'язанні певного завдання (текучий інтелект), зі старістю згасають.

Е. Біалісток та її колеги з Йоркського університету в м. Торонто (Канада) проаналізували результати експериментального теста на увагу “Simon Task" (вимірюючи час реакції та аспекти когнітивного процесу, що згасає з віком). У тестуванні взяли участь 154 одномовних і двомовних добровольців у віці 30-88 років. Було встановлено, що білінгви здатні краще управляти своєю увагою, справляючись зі складними або швидко мінливими завданнями. Справжня робота відкриває цікаві перспективи для лікування деяких серйозних захворювань (наприклад, хвороби Альцгеймера й старечого недоумства (сенільної деменції)): якщо результати будуть підтверджені подальшими дослідженнями, можна буде говорити про те, що двомовність може уповільнити непатологічне згасання когнітивних функцій за умови старіння.

Отже, білінгвізм має значні переваги, особливо якщо дитина 3 народження знаходиться під впливом двох мов і спілкування на них стає лінгвістичною звичкою.

До недоліків зазвичай відносять пізніший початок мовлення у двомовних дітей в порівнянні з одномовними, менший словниковий запас білінгвів, меншу швидкість у пошуку слів і метамовну інтерференцію. Однак, як уже зазначалося, початок мовлення в білінгвів входить у параметри нормального розвитку дітей і в контекст відмінного розуміння. На думку Янко-Уорралл, «білінгви досягають стадії розвитку семантики на 2-3 роки раніше своїх одномовних ровесників» [8, с. 1398]. Вони мають два «ментальних словника» й, можливо, тому на перших порах це ускладнює пошук потрібного слова для висловлювання. У роботах Е. Біалісток також зазначається, що білінгви зазвичай мають менший лексичний запас у кожній з окремо взятих мов, але в сумі вони знають більше 
слів у порівнянні з монолінгвами [7, с. 295]. Одиниці мови, які вживали в розмові або у внутрішній мові, часто є гіперонімами. А за думкою Т. Тешнер, загальна кількість слів у лексиконі двомовних і одномовних дітей приблизно однакова, як і приріст лексикону за один і той же період. Це пояснюється тим, що білінгви частіше засвоюють слова, які позначають нові об’єкти й події, ніж еквіваленти в обох мовах [3].

Роботи, присвячені вивченню мовної інтерференції на пізніших етапах розвитку, показують, що, хоча двомовні діти й змішують слова й структури двох мов, у багатьох випадках вони переходять 3 однієї мови на іншу не тому, що плутаються, а для досягнення особливих комунікативних ефектів [4]. Наприклад, кажучи мовою А, переходять на мову В, щоб передати щось сказане кимось на мові В; можуть переходити 3 мови на мову залежно від теми розмови або просто «грати» 3 мовами. Крім цього, змішання мов у більшості випадків не означає лінгвістичний хаос, тому що підпорядковується певним граматичним правилам і зазвичай проявляється в розмові з іншими білінгвами, а не 3 монолінгвами. Дитина буде більше змішувати мови, якщо самі батьки змішують їх, розмовляючи з нею або між собою.

Н.О. Бурейко підкреслює, що феномен мовного змішування варіюється від індивідуума до індивідуума, а також від сімейних ситуацій і від людей, з якими діти спілкуються [1].

А.М. Паділла й Е. Лієбман [11, с. 38], описуючи інтерференцію в мові білінгвів на лексичному рівні, помічають, що елементами, які найчастіше заміщаються всередині фрази, є іменники, за ними слідують приставки дієслів, дієслова, прикметники. Часто діти змішують мови через брак певних слів, які вони запозичують в іншій мові, вставляючи слова з однієї мови у висловлювання на іншому. Швидше за все йдеться про той же лінгвістичний процес, який спостерігається в монолінгвів: спочатку вони використовують невелику кількість наявних у них лексичних елементів, не завжди правильно вживаючи їх, і тільки пізніше, з розширенням словника, слова використовуються точніше. Іноді дитина просто не встигає повністю перемикнутися на іншу мову (повернувшись, наприклад, зі школи, продовжує перебувати під впливом місцевої мови).

M.M. Віхмар вважає, що проблему не потрібно обмежувати рамками мовного дефіциту й тимчасової нестачі еквівалентів, тому що на пізніших етапах розвитку, вже за наявності еквівалентів у двох мовах, продовжують відзначатися випадки лексичної інтерференції. На думку автора, необхідно формувати усвідомлення вживання двох мов, що дасть дитині мотивацію для усунення змішаних конструкцій і для вибору мови залежно від співрозмовника. Самі батьки, які намагаються розділяти свої мови, іноді несвідомо можуть продукувати змішані висловлювання в певних ситуаціях: наприклад, використовувати лексичні елементи, знайомі дитині тільки в одній мові або відомі також і в іншій, для спрощення комунікації або просто для привернення уваги.

Діти дуже чутливі до мовної поведінки й звичок дорослих і відразу ж помічають, яке місце відведено другій мові в сім'ї. Для досягнення когнітивних переваг білінгвізму важливо, щоб обидві мови мали вагоме значення не тільки в родині, а й у суспільстві. А для цього необхідно показувати дитині, що спілкування обома мовами можливо в будьяких ситуаціях і з багатьма іншими людьми.

Вивчення другої мови розширює ментальні кордони дитини, яка 3 культурного й лінгвістичного боку буде підготовленішою до вступу в життя: раніше зрозуміє, що існує не тільки ії будинок і країна, не тільки ії світ, але також інші країни 3 іншими мовами й традиціями, буде багатшою внутрішньо й менш схильною до упереджень. У сучасному світі дуже важливо бути готовим до нестандартних ситуацій, дивитися на речі під різними кутами зору, аналізувати складну інформацію, формулювати гіпотези, в потрібний момент знаходити відповідну ідею, входити в положення інших людей, володіти мисте- 
цтвом успішного й переконливого спілкування. Тут і проявляється сила білінгвізму. Світ, в якому ми живемо, складний, і хто зможе зрозуміти й підпорядкувати собі цю складність - виявиться на крок попереду.

Мовне розмаїття та мультилінгвізм є надбанням людства, це наше історичне й культурне багатство, i, крім того, вивчення процесу освоєння мов - можливість глибокого пізнання механізмів людського мозку.

\title{
Список використаної літератури
}

1. Бурейко Н.О. Методологічні засади психологічного дослідження білінгвів у наукових підходах до психолінгвістичної типології білінгвізму. Вісник ХНПУ. Серія «Психологія». Випуск 48. Харків : ХНПУ, 2014. С. 22-29.

2. Выготский Л.С. Мышление и речь. Москва : Лабиринт, 2001. 368 с.

3. Гулий Ю.І. Індивідуально-психологічні особливості білінгва в ситуації російсько-української двомовності : автореф. ... канд. психол. наук : 19.00.01. Харків, 1998. 18 с.

4. Засєкіна Л.В. Психолінгвістична діагностика : навчальний посібник. Луцьк : РВВ «Вежа» Волин. нац. ун-ту ім. Лесі Українки, 2008. 188 с.

5. Морозова И.С. Технологии оптимизации речевой деятельности личности в условиях билингвизма. Кемерово : Кузбасс. вуз. издат, 2008. 159 с.

6. Ben-Zeev S. Bilingualism and cognitive development Bilingualism and Language Disability . 1984. 1 (XIV, 255). P. 55-80.

7. Bialystok E., Craik F.I.M., Klein R., Viswanathan M. Bilingualism, aging, and cognitive control: Evidence from the Simon task. Psychology and Aging. 2004. No. 19. P. 290-303.

8. Ianco-Worrall A.D. Bilingualism and cognitive development. Child Development. Vol. 43. No. 4 (Dec., 1972). P. 1390-1400.

9. Mechelli A., Crossley N.A, Scott J., Ellison-Wright I. Neuroimaging distinction between neurological and psychiatric disorders. Br J Psychiatry. 2015 Nov. No. 207 (5). P. 429-434.

10. Petitto L.A. New Discoveries From the Bilingual Brain and Mind Across the Life Span: Implications for Education. International Journal of Mind, Brain and Education. 2009. No. 3 (4). P. 185-197

11. Padilla A.M., Liebman E. Language acquisition in the bilingual child. The Bilingual Review. 1975. No. 2. P. 34-55.

\section{INFLUENCE OF BILINGUALISM ON THE COGNITIVE DEVELOPMENT OF PERSONALITY}

\author{
Yana Kaimanova \\ Donetsk Institute of the Interregional Academy of Personnel Management, \\ 12, Uralska str., Kramatorsk, Ukraine, 84333 \\ e-mail: kramatorsk.institute.maup@gmail.com \\ Nadiia Riabokon \\ Donetsk Institute of the Interregional Academy of Personnel Management, \\ 12, Uralska str., Kramatorsk, Ukraine, 84333 \\ e-mail: kramatorsk.institute.maup@gmail.com
}

The article addresses the latest researches which is devoted to the influence of bilingualism on the cognitive development of personality. Recent experimental studies have not only broken the myth of the harm of bilingual personality development, but have shown that it provides much more than just knowledge of two languages. With the help of languages we know the world in all its diversity, each learnt language opens us new means of perception, thinking and cognition. Learning a new language, at the same time a 
person learns a new world. Bilingualism expands the boundaries of our thinking and cognition. Based on the comparative analysis, it shows the advantages of children and adults who are in a bilingual environment from birth. These advantages lie in the presence of metalinguistic abilities that allow in particular to increase the speed of learning; in a better development of executive functions (executive control, attention, ability to plan actions, concentration) than monolinguals of the same age has, which are important not only for taking verbal tasks, but also for managing any activity. As well it shows the influence of bilingualism on cognitive decentration, the ability to learn other languages, the formation of a high level of social sensitivity, which refers to both verbal and nonverbal communication (interpretation of facial expressions, gestures, intonation) and expresses in the most adequate reaction to language and communicative behavior of people around. Bilingualism expands the boundaries of thinking and cognition. The exploitation of a new language leads to the further development and enrichment of the individual's personality in the linguistic, cognitive, communicative aspects.

Bilingualism stimulates creativity, contributes to the development of divergent thinking, which allows to consider many possible solutions to the same problem and, as a result, to produce creative ideas. Knowledge of two languages expands the mental boundaries of a child who will be better prepared to enter life than his or her age-mates from a cultural and linguistic point of view.

Key words: bilingualism, monolingual, cognitive development, executive functions, decentralization. 